\title{
Fitness and therapeutic potential of intermittent hypoxia training: a matter of dose
}

\author{
T.V. Serebrovska ${ }^{1}$, Z.O. Serebrovska ${ }^{1}$, E. Egorov ${ }^{2}$ \\ ${ }_{1}^{1}$ Bogomoletz Institute of Physiology, Kiev, Ukraine, e-mail: sereb@biph.kiev.ua; \\ ${ }^{2}$ CELLGYM Technologies GmbH, Berlin, Germany
}

\begin{abstract}
The introduction of different methods of intermittent hypoxic training (IHT) into fitness, sports, military and medical practice has raised a lot of questions about the most beneficial regimens of such treatment and their optimal instrumental implementation. Low doses of hypoxia might not be sufficient stimuli to mobilize adaptive mechanisms, while severe or prolonged hypoxia may provoke dangerous pathological processes. In this review, we pay attention to narrow practical question of the most effective and convenient technology of IHT implementation, notably the inhalation of hypoxic gas mixtures. Data strongly suggest that in humans the training with $15-13 \%$ inhaled oxygen ( $\mathrm{FiO}_{2}$ ) at various time characteristics does not provide marked positive changes. Short-term daily sessions consisting 3-4 bouts of 5-7 min exposures to $12-10 \% \mathrm{FiO}_{2}$ alternating with equal durations of normoxia for 2-3 weeks have been shown as a most beneficial without maladaptive consequences for fitness and treatment of some diseases. More severe or longer intermittent hypoxia protocols must be accompanied by strict monitoring of blood oxygen saturation $\left(\mathrm{Sp} \mathrm{O}_{2}\right)$, electrocardiogram, breathing pattern and arterial blood pressure in order to avoid unexpected undesirable individual reactions. For sports purposes, the reduction of oxygen content to individually tolerable level for some minutes is justified as far as it maximizes benefits. However, such regimen requires preliminary diagnostics of individual hypoxic tolerance and cardio-respiratory reactivity as well as rigorous monitoring of vital functions during IHT and good feedback device. The use of oxygen concentrations below $12 \%$ for treatment of diseases, especially in children and the elderly, are required substantial additional research. Recently, a new mode of adaptive training was explored, which combines periods of hypoxia $\left(12-10 \% \mathrm{FiO}_{2}\right)$ and hyperoxia $\left(30-35 \% \mathrm{FiO}_{2}\right)$. Limited evidences suggest that such regime can reduce the time of recovery periods, that is shorten the duration of sessions. However, there is still no strong comparative evidence for humans that this method is much more efficient than hypoxic-normoxic mode. We appeal to all scientists working in the field of IHT not to hide their negative results but publish all observations in the open press. It will make a significant contribution in developing of common guidelines for IHT implementation to improve public health of our Planet.
\end{abstract}

Key words: intermittent hypoxia training; mode of IHT; hypoxic-hyperoxic training; hemoglobin oxygen saturation; adaptation to hypoxia

\section{INTRODUCTION}

The proliferation of intermittent hypoxic training/treatment (IHT) methods in fitness, sports, military and medical practice during recent decades has caused debate about the most beneficial regimens of hypoxic training and methods of their instrumental implementation. Intermittent hypoxia (periodic, interval, cyclic hypoxia, hypoxic preconditioning - diff. terminology) is drug-free method that has (c) T.V. Serebrovska, Z.O. Serebrovska, E. Egorov been routinely used by about 2 million patients in the last 30 years and revealed good and satisfactory results in $75-95 \%$ of cases [1, 2]. Beneficial results of IHT application were obtained for enhancement of physical and mental operability, the prevention of premature aging, the achievement of high results in sports, increased tolerance to adverse environmental factors, for altitude pre-acclimatization, as well as for the treatment and prevention of various diseases. 
The mechanisms underlying the effects of hypoxic training at all levels - from systemic physiological reactions to the genome - are widely debated. This topic is the subject of many articles, reviews and monographs. To avoid repetition we refer readers to the most recent reviews [3-10].

The biological responses to intermittent hypoxia may be adaptive or maladaptive, depending on the severity of the hypoxemia, its frequency of occurrence, its duration, and, importantly, the "pattern" and timing of each of the $\mathrm{HbO}_{2}$ desaturation/ resaturation cycles $[7,11]$. Many types of protocol with different numbers of hypoxia episodes, severity, and total exposure duration have been used by investigators, and these combinations may have resulted in various physiological responses. Mode of hypoxic influence (depth, duration, and intermittence) is critical for the determination of beneficial or detrimental effects of IHT. Low doses of hypoxia might not be sufficient stimuli to mobilize adaptive mechanisms, while severe or prolonged hypoxia may provoke dangerous pathological processes.

The question arises: what is the concentration of inhaled oxygen and temporal characteristics of hypoxic pattern that may be relatively safe and useful, and what level of hypoxia requires unconditional monitoring of functional parameters and clear alarm-service. In this review, we will pay attention to narrow practical question of IHT application in human practice and provide unbiased analysis of hypoxia training protocols that use the most effective and convenient technology - the inhalation of hypoxic gas mixtures.

\section{Regimes of IHT with hypoxic gas mixtures inhalation: recommended doses and potential adverse effects}

Traditional treatment protocols for IHT comprises repeated exposures to low oxygen atmosphere breathing, altered with breathing ambient air. However, hypoxic regimens which are used for IHT implementation in human practice vary broadly in terms of severity of hypoxia (from $2 \%$ to $18 \%$ inspired oxygen), duration of hypoxic and normoxic episodes (from 15-30 s to $12 \mathrm{~h}$ ), the number of cycles per day (from 3 to 25 sessions), the duration of IHT course (2-90 days), etc. Such diversity is largely dependent on a contingent designed for this training: for athletes of varying skill, mountain hikers, soldiers of alpine troops, pregnant women, elderly people who want to extend their active life, or patients for the prevention or treatment of various diseases.

Some characteristics of different regimes are described in recent reviews $[4,5,7,8,12,13]$. Historically, first methodical recommendations for IHT implementation in human practice were published by the Russian Health Ministry in 1988 which recommended the inhalation of $10-$ $12 \% \mathrm{O}_{2}$ during 5 - min periods with 5 min rest, 1 $\mathrm{h}$ per session, 1-4 weeks per course for the treatment of various diseases. The evidence base was represented by the investigations of R. Strelkov, A. Chizhov, H.Gurvich, A.Kolchinskaya, N. Geppe and many others (look the review [14]). Most achievements in IHT practical implementation were based on a thorough study of the mechanisms of both positive and negative IHT actions in sport practice and clinical pilot studies. Unfortunately, serious research on the use of IHT in rejuvenation practice and fitness is still not presented in the medical literature.

In the Table we presented the most typical literature data concerning the use of IHT in human practice during last 2 years, as well as some classical works of the past. Data are ranked in order of decreasing oxygen concentration in the inspired gas. Human investigations strongly suggest that the training with $15-13 \%$ inhaled oxygen $\left(\mathrm{FiO}_{2}\right)$ at various time characteristics do not provide any positive changes [15-24]. $12-10 \% \mathrm{FiO}_{2}$ is the most common concentration caused a positive effect [25-39, 48, 49]. None of the articles that use such concentrations describe adverse effects. There are few papers which documented adverse effects, but starting with $8-9 \% \mathrm{FiO}_{2}$ [40-47]. All study results cited in the Table as well as other known papers 
Regimens of IHT that use the inhalation of gas mixtures for humans

(The papers presented in order of decreasing inspired oxygen concentration that used for research)

\begin{tabular}{|c|c|c|c|}
\hline Authors & Subjects & Regimen of IHT & Results \\
\hline$[15]$ & $\begin{array}{l}12 \text { healthy } \\
\text { participan }\end{array}$ & $\begin{array}{l}18-15 \% \mathrm{FiO}_{2}, 10 \mathrm{~min}, \\
\text { ergometer at } 20 \% \text { peak } \mathrm{VO}_{2}\end{array}$ & Hypoxia has no effects on cognitive function \\
\hline$[16]$ & $\begin{array}{l}9 \text { male games } \\
\text { players }\end{array}$ & $\begin{array}{l}17 \% \mathrm{FiO}_{2} \text { at } 40 \mathrm{~min} \text { cy- } \\
\text { cling intermittent } 5 \mathrm{~s} \text { sprint } \\
\text { protocol }\end{array}$ & $\begin{array}{l}\text { Peak and mean power output and total work done } \\
\text { reduced, Heart rate was higher and } \mathrm{SaO} 2 \text { lower dur- } \\
\text { ing HYP. The results suggest athletes will be at a } \\
\text { disadvantage when performing intermittent sprinting } \\
\text { at moderate altitude }\end{array}$ \\
\hline$[17]$ & \begin{tabular}{l|}
22 subjects age \\
$17-25 \mathrm{yr}$
\end{tabular} & $\begin{array}{l}16.4-14.5 \% \mathrm{FiO}_{2} \text {, exercises } \\
\text { at } 6 \text {-h hypoxia weekly, } 4 \\
\text { weeks }\end{array}$ & $\begin{array}{l}\text { Weight loss, improvement of blood pressure, no ef- } \\
\text { fect on brachial-ankle pulse wave velocity }\end{array}$ \\
\hline$[18]$ & $\begin{array}{l}10 \text { untrained } \\
\text { men }\end{array}$ & $\begin{array}{l}15 \% \mathrm{FiO}_{2} \text {, five sets of } 15 \\
\text { repetitions of squat exercise }\end{array}$ & $\begin{array}{l}\text { No significant differences in blood lactate, growth } \\
\text { hormone, total testosterone and cortisol under nor- } \\
\text { mixia and hypoxia, i.e. low-intensity resistance exer- } \\
\text { cise performed under mild hypoxia does not induce } \\
\text { greater anabolic hormonal responses }\end{array}$ \\
\hline$[19]$ & $\begin{array}{l}18 \text { male trained } \\
\text { triathletes }\end{array}$ & $\begin{array}{l}14.5-15 \% \mathrm{FiO} 2 \text {, two } \\
60 \text {-min sessions per week } \\
\text { during } 7 \text { weeks }\end{array}$ & $\begin{array}{l}\text { Hemoglobin and erythrocytes values increased, } \\
\text { aerobic performance and physiological variables did } \\
\text { not increase }\end{array}$ \\
\hline$[20]$ & $\begin{array}{l}9 \text { physically } \\
\text { active men }\end{array}$ & $\begin{array}{l}14,5 \% \mathrm{FiO}_{2}, 25 \mathrm{~min} \text { train- } \\
\text { ing sessions, } 3 \mathrm{wk}\end{array}$ & $\begin{array}{l}\text { No effect on time-to-exhaustion during incremental } \\
\text { exercise and muscle metabolite concentrations,i.e. } \\
\text { IHT does not alter muscle metabolic responses }\end{array}$ \\
\hline$[21]$ & $\begin{array}{l}10 \text { trained male } \\
\text { team sport } \\
\text { athletes }\end{array}$ & $\begin{array}{l}14.5 \% \mathrm{FiO} 2 \text {, repeat-sprint } \\
\text { training session comprised } \\
3 \text { sets of } 9 \times 5 \mathrm{~s} \text { maximal } \\
\text { sprints commencing every } \\
25 \mathrm{~s}\end{array}$ & $\begin{array}{l}\text { No post-exercise inflammation, little effect on oxi- } \\
\text { dative stress }\end{array}$ \\
\hline$[22]$ & $\begin{array}{l}16 \text { highly } \\
\text { trained foot- } \\
\text { ballers }\end{array}$ & $\begin{array}{l}14.3 \% \mathrm{FiO}_{2}, 60 \mathrm{~min} \text { per } \\
\text { sprint training, } 2 \mathrm{~d} \cdot \mathrm{wk}, 5 \\
\text { weeks }\end{array}$ & $\begin{array}{l}\text { Maximal aerobic speed, lower-limb explosive power } \\
\text { and sprint decrement remained unchanged; repeated- } \\
\text { sprint times and repeated-agility improved }\end{array}$ \\
\hline$[23]$ & \begin{tabular}{|l|}
16 heathy sub- \\
jects
\end{tabular} & $\begin{array}{l}13.8 \% \mathrm{FiO} 2 \text {, three } 10 \text {-hour } \\
\text { exposures }\end{array}$ & $\begin{array}{l}\text { SOD, GPX and catalase activities, advanced } \\
\text { oxidation protein products increased }\end{array}$ \\
\hline$[24]$ & $\begin{array}{l}18 \text { male } \\
\text { cyclists }\end{array}$ & $\begin{array}{l}\sim 13-14 \% \text { FiO2, } 5 \text { training } \\
\text { sessions ( } 75 \text { min hypoxic } \\
\text { period) per week during } 3 \\
\text { weeks. }\end{array}$ & $\begin{array}{l}\text { Peak power output increased but VO2max did not; } \\
\text { no differences in monocarboxylate lactate transport- } \\
\text { er protein content. There are no additional benefits } \\
\text { of IHT compared to normoxic training }\end{array}$ \\
\hline$[25]$ & $\begin{array}{l}55 \text { children } 6 \\
\text { to } 17 \text { yr with } \\
\text { symptoms of } \\
\text { bronchospasm }\end{array}$ & $\begin{array}{l}12 \% \mathrm{FiO}_{2} \text {, three } 15-\min \\
\text { sessions per day with } 10- \\
\text { min breaks during } 7-14 \\
\text { days }\end{array}$ & $\begin{array}{l}\text { Lung vital capacity and breath-holding time } \\
\text { increased, bronchial obstruction and heart rate } \\
\text { decreased }\end{array}$ \\
\hline$[26]$ & $\begin{array}{l}8 \text { healthy male } \\
\text { subjects }\end{array}$ & $\begin{array}{l}12 \% \mathrm{O} 2 \text { for } 5 \text { min followed } \\
\text { by } 5 \text { min of normoxia for } 1 \\
\text { h/d during } 10 \text { days }\end{array}$ & $\begin{array}{l}\text { Ventilatory response to hypoxia increased, cerebro- } \\
\text { vascular sensitivity to } \mathrm{CO}_{2} \text { remained unchanged }\end{array}$ \\
\hline
\end{tabular}




\begin{tabular}{|c|c|c|c|}
\hline [27] & \begin{tabular}{l|}
48 children 6 \\
-17 yr from \\
radioactive ter- \\
ritories
\end{tabular} & $\begin{array}{l}12 \% \mathrm{FiO}_{2}, \text { three } 15-\mathrm{min} \\
\text { sessions per day with } 10- \\
\text { min breaks during } 7-14 \\
\text { days }\end{array}$ & $\begin{array}{l}\text { Latent period of complex visual-motor response } \\
\text { to one of three colors reduced, personal anxiety } \\
\text { decreased }\end{array}$ \\
\hline [28] & $\begin{array}{l}14 \text { healthy, } 60- \\
\text { to } 74-\text { yr-old } \\
\text { men }\end{array}$ & $\begin{array}{l}12 \% \mathrm{FiO}_{2}, 3-5 \text { min , with } \\
5 \text { min breaks, 4/day during } \\
10 \text { days }\end{array}$ & $\begin{array}{l}\text { No changes in hemodynamic indices and work } \\
\text { capacity in routinely daily exercised subjects and } \\
\text { increased submaximal work and anaerobic threshold } \\
\text { in untrained men }\end{array}$ \\
\hline [29] & $\begin{array}{l}45 \text { elderly } \\
\text { patients with } \\
\text { stable angina }\end{array}$ & $\begin{array}{l}12 \% \mathrm{FiO}_{2}, 5-7 \mathrm{~min}, \text { with } \\
5 \text { min breaks, 4/day, 10-12 } \\
\text { days }\end{array}$ & $\begin{array}{l}\text { Reduction in clinical symptoms of angina and dura- } \\
\text { tion of daily myocardial ischemia, normalization of } \\
\text { lipid metabolism and increase exercise tolerance, } \\
\text { normalization of microcirculation }\end{array}$ \\
\hline$[30]$ & \begin{tabular}{l|}
16 children \\
aged $9-13$ yr \\
with bronchial \\
asthma
\end{tabular} & $\begin{array}{l}12 \% \mathrm{FiO}_{2}, 3-5 \text { min, with } \\
5 \text { min breaks, 3/day during } \\
2 \text { weeks }\end{array}$ & $\begin{array}{l}\text { Decline in breath shortness and feelings of chest } \\
\text { congestion, diminishing of cough and sputum, } \\
\text { attacks of asphyxia disappeared or became less } \\
\text { frequent, increased HVR, no changes in airway } \\
\text { conductance }\end{array}$ \\
\hline$[31]$ & $\begin{array}{l}20 \text { endurance- } \\
\text { trained men }\end{array}$ & $\begin{array}{l}11 \% \mathrm{FiO}_{2} \text { on days } 1-7 \text { and } \\
10 \% \mathrm{O} 2 \text { on days } 8-15 ; 10 \\
\text { bouts during } 15 \text { days }\end{array}$ & No effect on aerobic or anaerobic performance \\
\hline$[32]$ & \begin{tabular}{l|}
15 athletes \\
with overtrain- \\
ing syndrome
\end{tabular} & $\begin{array}{l}10 \% \mathrm{FiO}_{2} \text { with hyper- } \\
\text { oxic breaks }\left(30 \% \mathrm{O}_{2}\right), 6-8 \\
\text { cycles, three times a week } \\
\text { over } 4 \text { weeks }\end{array}$ & $\begin{array}{l}\text { Exercise performance and sympatho-parasympathet- } \\
\text { ic index improved, hematological parameters were } \\
\text { unchanged }\end{array}$ \\
\hline [33] & $\begin{array}{l}8 \text { young non- } \\
\text { smokers }\end{array}$ & $\begin{array}{l}10 \% \mathrm{FiO}_{2} \text {, five to ten } 5-6- \\
\text { min sessions per day with } \\
4 \text {-min breaks during } 14 \\
\text { days }\end{array}$ & $\begin{array}{l}\text { IH exposures significantly diminish variations of } \\
\text { cerebral perfusion in response to hypercapnia and } \\
\text { hypocapnia without compromising cerebral tissue } \\
\text { oxygenation. No adverse effects }\end{array}$ \\
\hline$[34]$ & $\begin{array}{l}\text { patients with } \\
\text { stage } 1 \text { arterial } \\
\text { hypertension }\end{array}$ & $\begin{array}{l}10 \% \mathrm{FiO}_{2}, \text { four to ten } \\
3 \text {-min sessions per day with } \\
3 \text {-min breaks during } 14 \\
\text { days }\end{array}$ & $\begin{array}{l}\text { Increased nitric oxide synthesis and decreased blood } \\
\text { pressure }\end{array}$ \\
\hline$[35]$ & $\begin{array}{l}42 \text { patients } \\
\text { with BA and } \\
14 \text { patients } \\
\text { with COB } \\
\end{array}$ & $\begin{array}{l}10 \% \mathrm{FiO}_{2}, 5 \mathrm{~min}, \text { with } 5 \\
\text { min breaks, } 20-25 \text { sessions }\end{array}$ & $\begin{array}{l}\text { Positive effect is obtained in } 76 \% \text { of patients with } \\
\text { BA and } 92.8 \% \text { of patients with COB } 1\end{array}$ \\
\hline [36] & $\begin{array}{l}8 \text { young non- } \\
\text { smokers }\end{array}$ & $\begin{array}{l}10 \% \mathrm{FiO}_{2} \text {, five to ten } 5-6 \text { - } \\
\text { min sessions per day with } \\
\text { 4-min breaks during } 14 \\
\text { days }\end{array}$ & $\begin{array}{l}\text { A rightward shift in the oxyhemoglobin equilib- } \\
\text { rium response, attenuated tachycardiac response to } \\
\text { hypoxia while significantly enhancing normoxic } \\
\text { R-R interval variability in low-frequency and high- } \\
\text { frequency spectra without changes in arterial blood } \\
\text { pressure at rest or during hypoxia, i.e. the enhance- } \\
\text { ment of arterial O2 delivery and improvement of } \\
\text { vagal control of HR. }\end{array}$ \\
\hline
\end{tabular}




\begin{tabular}{|c|c|c|c|}
\hline$[37]$ & \begin{tabular}{|l|}
123 patients \\
with hyperten- \\
sion stage I \\
and II.
\end{tabular} & $\begin{array}{l}10 \% \mathrm{FiO}_{2}, 2-6 \mathrm{~min}+3-8 \\
\min \text { normoxia, } 5-12 \mathrm{cy}- \\
\text { cles } / \mathrm{d}, 15-30 \mathrm{~d}\end{array}$ & $\begin{array}{l}\text { Reduction of the arterial pressure, rise of physical } \\
\text { performance A pronounced depressor effect persist- } \\
\text { ed for }-6 \text { months in } 63 \text { patients }\end{array}$ \\
\hline$[38]$ & \begin{tabular}{|l|}
41 patients \\
with hyper- \\
tonic disease
\end{tabular} & $10 \% \mathrm{FiO}_{2}, 13-25$ sessions & $\begin{array}{l}\text { Arterial pressure and emotional tension decreased, } \\
\text { oxygen consumption and transport normalized. }\end{array}$ \\
\hline$[39]$ & $\begin{array}{l}10 \text { healthy } \\
\text { subjects }\end{array}$ & $\begin{array}{l}10 \% \mathrm{FiO}_{2}, \text { four } 5-\mathrm{min} \\
\text { bouts/day during } 2 \mathrm{wk}\end{array}$ & $\begin{array}{l}\text { Enhancement of innate immunity by mobilizing } \\
\text { circulating hematopoietic stem and progenitor cells, } \\
\text { activating neutrophils, and increasing circulating } \\
\text { complement and immunoglobulins. }\end{array}$ \\
\hline$[40]$ & $\begin{array}{l}19 \text { subjects } \\
\text { with chronic } \\
\text { incomplete spi- } \\
\text { nal cord injury }\end{array}$ & $\begin{array}{l}9 \% \text { FiO2, 90-sec with } 60- \\
\text { sec normoxic breaks, } 15 \\
\text { exposures during } 5 \text { days }\end{array}$ & Improved walking speed and distance. \\
\hline $\begin{array}{l}{[41,} \\
42]\end{array}$ & $\begin{array}{l}13 \text { individuals } \\
\text { with chronic, } \\
\text { incomplete spi- } \\
\text { nal cord injury }\end{array}$ & $\begin{array}{l}9 \% \mathrm{FiO} 2,15 \text { exposures } \\
\text { with } 1 \text {-min intervals }\end{array}$ & $\begin{array}{l}\text { Plantar flexion torque and ankle plantar flexor elec- } \\
\text { tromyogram activity increased, i.e. elicits sustained } \\
\text { increases in volitional somatic motor output. IHT } \\
\text { was not accompanied by increases in blood pressure } \\
\text { or changes in heart rate variability }\end{array}$ \\
\hline$[43]$ & $\begin{array}{l}26 \text { participants } \\
\text { with OSA }\end{array}$ & $\begin{array}{l}8-9 \% \mathrm{FiO} 2, \text { twelve } 4-\mathrm{min} \\
\text { episodes followed by a } \\
\text { single breath of } 100 \% \mathrm{O}_{2}\end{array}$ & $\begin{array}{l}\text { Chemoreflex sensitivity to hypoxia increased pro- } \\
\text { moting apneic events and ultimately exacerbating } \\
\text { breathing instability }\end{array}$ \\
\hline$[44]$ & $\begin{array}{l}12 \text { healthy } \\
\text { males }\end{array}$ & $\begin{array}{l}8-12 \% \mathrm{FiO}_{2} \\
(\mathrm{PETO} 2=45 \mathrm{Torr}), 6 \mathrm{~h} \text { on } \\
\text { three ocasions }\end{array}$ & $\begin{array}{l}\text { Increased resting ventilation and the HVR, TNF- } \alpha \\
\text { was decreased with only selective COX-2 inhibition, } \\
\text { i.e. inflammation does not contribute to human inter- } \\
\text { mittent hypoxia-induced respiratory plasticity }\end{array}$ \\
\hline$[45]$ & $\begin{array}{l}\text { One } 55 \text {-year- } \\
\text { old female with } \\
\text { a C4 chronic, } \\
\text { incomplete spi- } \\
\text { nal cord injury } \\
\end{array}$ & $\begin{array}{l}8 \% \text { O2, eight } 2 \text { min expo- } \\
\text { sures with } 2 \text { min normoxia } \\
\text { during } 10 \text { days }\end{array}$ & $\begin{array}{l}\text { Significant improvements in airflow generated in } \\
\text { response to applied inspiratory resistive load. No } \\
\text { significant changes in the respiratory perceptual } \\
\text { sensitivity to inspiratory resistive loads. }\end{array}$ \\
\hline$[46]$ & $\begin{array}{l}8 \text { individuals } \\
\text { with incom- } \\
\text { plete spinal } \\
\text { cord injury }\end{array}$ & $\begin{array}{l}8 \% \text { O2, eight } 2 \text { min expo- } \\
\text { sures with } 2 \text { min normoxia } \\
\text { during } 10 \text { days }\end{array}$ & $\begin{array}{l}\text { Minute ventilation increased, FVC and FEV-1 im- } \\
\text { proved, but the magnitude of ventilatory long-term } \\
\text { facilitation was not enhanced }\end{array}$ \\
\hline$[47]$ & $\begin{array}{l}8 \text { healthy adult } \\
\text { men }\end{array}$ & $\begin{array}{l}5 \% \mathrm{FiO}_{2} \text { until } \mathrm{SaO}_{2} \text { dropped } \\
\text { to } 85 \%(25 \text { hypoxic events/ } \\
\text { h),five hours }\end{array}$ & $\begin{array}{l}\text { Two fold up-regulation of the pro-inflammatory } \\
\text { gene toll receptor } 2 \text { that may lead to systemic in- } \\
\text { flammation, insulin resistance and atherosclerosis }\end{array}$ \\
\hline & & Rebreathing technique: & \\
\hline$[48]$ & $\begin{array}{l}29 \text { residents of } \\
\text { Chernobyl }\end{array}$ & $\begin{array}{l}\text { A decrease from } 20,9 \text { to } 9 \\
\% \mathrm{FiO}_{2} \text { during } 5 \text { min, three } \\
\text { daily sessions with } 15 \mathrm{~min} \\
\text { breaks, } 10 \text { days }\end{array}$ & $\begin{array}{l}\text { normalizing effect on free radical processes; a } \\
\text { decrease in spontaneous and initiated blood chemilu- } \\
\text { minescence and MDA }\end{array}$ \\
\hline$[49]$ & \begin{tabular}{l|}
18 patients \\
with idiopathic \\
parkinsonism
\end{tabular} & $\begin{array}{l}\text { A decrease from } 20,9 \text { to } 9 \\
\% \mathrm{FiO}_{2} \text { during } 5 \text { min, three } \\
\text { daily sessions with } 10 \mathrm{~min} \\
\text { breaks, } 14 \text { days }\end{array}$ & $\begin{array}{l}\text { Increase in hypoxic ventilatory response, no changes } \\
\text { in hypercapnic ventilatory response, decrease in } \\
\text { DOPA blood concentration, improvement of respira- } \\
\text { tory system functioning }\end{array}$ \\
\hline
\end{tabular}


show that there have been no reported adverse physiological effects when users have followed the recommendations [12]: "a few minutes of targeted $\mathrm{SpO}_{2} 75-88 \%$ at rest, alternated with reoxygenation".

In a recent review [5], it was also suggested that modest levels of hypoxia $\left(9-16 \% \mathrm{O}_{2}\right)$ and a relatively low number of exposures (3-15 episodes per day) seem to elicit beneficial effects without pathology, whereas severe hypoxia $\left(2-8 \% \mathrm{O}_{2}\right)$ characterized by an extensive amount of episodes (48-2,400 exposures per day) elicits progressively greater pathology. In the latest review Astorino [8] analyzing the efficacy of acute intermittent hypoxia on physical function and health status in humans with spinal cord injury comes to the conclusion that $2 \mathrm{~min}$ exposures to intermittent hypoxia equivalent to $8-9 \% \mathrm{O}_{2}$ interspersed with 2 min normoxic exposures during 10 days can be successfully used to treat such patients.

Thus, according to numerous data, short exposures to $12-10 \% \mathrm{O}_{2}$ are harmless in most cases.

One could see the correspondence between such data distribution and the critical points of oxyhemoglobin dissociation curve. It is known [50-52] that during the decline of oxygen partial pressure in arterial blood from $\sim 95 \mathrm{~mm} \mathrm{Hg}$ (corresponding to $20,9 \% \mathrm{FiO}_{2}$ ) to $80 \mathrm{mmHg}$, hemoglobin oxygen saturation decreases insignificantly, only by $5 \%$. Then, from 80 to $50 \mathrm{~mm} \mathrm{Hg}$ (corresponding to $\sim 10-12 \% \mathrm{FiO}_{2}$ ), oxygen saturation falls by $15 \%$. After $50 \mathrm{~mm}$ $\mathrm{Hg}$ the concentration of oxyhemoglobin in arterial blood falls rapidly. In this part of the curve the gradient of a few $\mathrm{mm} \mathrm{Hg}$ in the inhaled air can cause significant changes in oxygen supply slowing down ATP synthesis that is a direct destructive effect. As Dempsey and Morgan [6] have written in their last review, the sigmoid shape of the $\mathrm{HbO}_{2}$ disassociation curve permits substantial (up to one-third) reductions from the normal arterial $\mathrm{PO}_{2}$ before serious reductions occur in arterial $\mathrm{O}_{2}$ saturation and content and therefore in $\mathrm{O}_{2}$ transport. In the range of 80 to
$50 \mathrm{~mm} \mathrm{Hg}$, there is such a degree of hypoxia when the supply of reduced coenzymes in the electron transport chain of mitochondria slows down. This in no way affects the rate of ATP synthesis, but increases the concentration of superoxide anion which activates numerous intracellular adaptation mechanisms [53, 54]. Thus, the data obtained by various authors about IHT therapeutic effects under the inhalation of $12 \% \mathrm{O}_{2}$ and less fits into this picture.

However, further reduction of inspired oxygen concentration in weak individuals and patients with different pathology may result in adverse changes. Besides oxyhemoglobin dissociation curve, there are other factors affecting the tissue oxygenation. For example, during blood acidification that can occur at different pathologies, critical points at oxyhemoglobin dissociation curve shift toward higher oxygen concentrations (not 50 but $60 \mathrm{mmHg}$ ). During anemia blood oxygen capacity is reduced, thus tissue hypoxia develops faster. Intoxication alters the zeta potential of red blood cells and decreases their functionality. This also reduces the degree of tissue oxygenation. The data presented in the table suggest that for healthy subjects the short-term inhalation of $10 \% \mathrm{O}_{2}$ is not dangerous, and such training does not require constant medical supervision. As for the patients and older people, the use of $12-10 \% \mathrm{FiO}_{2}$ can be considered effective and safe just only if the monitoring of the most important physiological functions takes place. The biological costs of many types of hypoxic adaptations can sometimes outweigh their benefits [12].

Regarding the optimization of the duration of hypoxic exposures and the length of IHT course, it worth to mention the results of earlier work of Foster et al. [55]. Authors provided the comparison of two protocols of normobaric, isocapnic, intermittent hypoxia: short-duration intermittent hypoxia with $12 \% \mathrm{O}_{2}$ separated by $5 \mathrm{~min}$ of normoxia for $1 \mathrm{~h}$, or long-duration intermittent hypoxia $30 \mathrm{~min}$ of $12 \% \mathrm{O}_{2}$. Both groups had 10 exposures over a 12 day period. Measuring hypoxic ventilatory response (HVR), 
blood pressure, heart rate, arterial oxyhemoglobin saturation and cerebral tissue oxygen saturation, authors concluded that both short- and long-duration intermittent hypoxia had similar effects on the ventilatory and cardiovascular responses, thus the long-term hypoxic exposures can be successfully replaced by short-term impacts with the same result. These investigations also show that the break in training for one or two days do not significantly affect the outcome of the IHT course. These conclusions were also expressed by Katayama et al. [56, 57], Koehle et al. [58] and others. Later on, Katayama et al. [59] conducted a study using the hypoxic tent, which was supported by $12.3 \% \mathrm{O}_{2}$, one and 3 hours during the week. HVR growth in the group which trained 1 hour was no less than in the group that trained 3 hours. Thus, short-term regime impacts may have the same result as longer regime.

Experiments on animals also confirm that short cycles of hypoxic exposures alternating with normoxic periods are more effective than longer bouts or continuous daily hypoxic exposures [13, 60-61]. Powerful hypoxic-induced gene transcription factors (HIF-1/HIF-2 alpha) are activated very early upon hypoxic exposure, guaranteeing time-dependent up-regulation of cardiorespiratory and hematological responses aimed at limiting deficits in $\mathrm{O}_{2}$ transport [62]. As Dempsey and Morgan [6] have written, on the adaptive side, short-term exposures (via manipulation of $\mathrm{FiO}_{2}$ ) to a few weeks of daily sessions consisting of 10-15 1- to 2-min bouts of moderate isocapnic hypoxemia $\left(\mathrm{SpO}_{2} 75-80 \%\right)$ alternating with equal durations of normoxia have been shown to yield several benefits without maladaptive consequence.

The use of IHT in pediatrics requires special attention. Major achievements in this direction were made by scientists from the former Soviet Union [9]. Here we just briefly mention some papers to illustrate the mode of IHT for children.

A study of Anokhin and co-authors [63] applied IHT with a normobaric hypoxic stimulation with four sessions of $5 \mathrm{~min} 12-15 \% \mathrm{O}_{2}$, followed by 5 min normoxic interval, for 10 days in 200 children aged 4 to 14 years who suffered from bronchial asthma. Researchers from Brazil studied 48 adolescents (12-14 years of age) under three conditions: mild intermittent asthma; mild persistent asthma; and control [64]. They concluded that adolescents with mild persistent asthma have a greater capacity to adapt to hypoxia than do those with other types of asthma. In addition, Serebrovskaya et al. [30] used IHT for treatment of children (aged 9-13 years) with persistent atopic bronchial asthma in moderate form without the signs of respiratory insufficiency. Normobaric hypoxia was administered with a portable device "Hypoxytron", a modified closed spirometer with $\mathrm{CO}_{2}$ absorption [65]. The initial inspired gas had $20.9 \% \mathrm{O}_{2}$ that fell to $12 \%$ during first $60-90$ seconds of rebreathing, and then $\mathrm{O}_{2}$ was added gradually to the device to maintain inspired $\mathrm{O}_{2}$ at $12 \%$ for the remaining 3.5-4 min with a final arterial $\mathrm{O}_{2}$ saturation typically $89-92 \%$. All children easily tolerated the hypoxia periods without any untoward effects. Each IHT session consisted of four 5-7 min hypoxic periods, followed by $5 \mathrm{~min}$ interval with room air inspiration. Heart rate response to hypoxia became less pronounced and $\mathrm{SpO}_{2}$ fell less at $12 \% \mathrm{O}_{2}$ after the course, indicating IHT improved efficiency of cardiovascular system in supporting oxygen supply during hypoxia.

Thus, IHT represents a promising approach in prevention and treatment of bronchial asthma in childhood. The proper choice of the hypoxic dosage depending on individual's reactivity to hypoxia must be titrated for each patient to avoid negative effects of hypoxia and to augment the favorable ones.

\section{Hypoxic-hyperoxic exposures}

Recently, a new mode of adaptive training was explored, which combines periods of hypoxia and hyperoxia [66-69]. A novel principle of short-term periodic adaptive training by varying the oxygen level from hypo- to hyperoxia is substantiated both theoretically and experimentally. Studies supports the viewpoint 
that moderate periodic generation of free radical signal during hypoxic/hyperoxic bouts causes better induction of antioxidant enzyme protein synthesis then hypoxic/normoxic exposures, that may be an important trigger for specific adaptations.

Currently, this method is just beginning to enter the practice, so at this moment there are only a few papers in medical literature describing the results of such training in humans. Traditional protocols include alternating of breathing hypoxic gas mixtures $\left(10-12 \% \mathrm{FiO}_{2}\right)$ and periods of breathing hyperoxic mixture (about 30-35\% $\mathrm{O}_{2}$ ).

Combined hypoxic-hyperoxic training was used in the treatment of the metabolic syndrome [70]. The use of hypo-hyperoxic exposures leads to a significant reduction in body weight. It was achieved mainly by reducing fat mass accompanied by a reduction of total cholesterol, low-density lipoproteins, fasting plasma glucose, optimization of blood pressure, increased hypoxic stability, physical endurance, improved mental status.

In more recent publication, Glazachev \& Dudnik [67] provided the hypoxic test (10 min breathing with $10 \% \mathrm{FiO}_{2}$ followed by $30 \% \mathrm{FiO}_{2}$ ) in 30 healthy young men and described two different types of microcirculatory reactions: among the subjects sensitive to hypoxia such test led to a significant reduction in $\mathrm{SpO}_{2}$ in the absence of changes in the microcirculation regulation; among the subjects resistant to hypoxia the test leads to the nutritive blood flow activation by increasing the initially lower endothelium-dependent and neurogenic sympathetic components in regulation of microhaemodynamics activity, reduction of blood shunting.

Susta et al [32] investigated sportsmen with overtraining syndrome with application a conditioning program consisting of repeated exposures to hypoxia $\left(10 \% \mathrm{FiO}_{2}\right)$ and hyperoxia $\left(30 \% \mathrm{FiO}_{2}\right), 6-8$ cycles (total time $45 \mathrm{~min}-1$ h), three times a week, delivered 1.5-2 h after a low-intensity exercise session over 4 weeks.
This pilot study showed that such training can facilitate functional recovery among athletes with overtraining syndrome in a relatively short time.

\section{Potential Side Effects}

The maladaptive side of intermittent hypoxia of pathological origin is mainly considered in the context of obstructive sleep apnea (OSA). Mechanisms of maladaptive responses are very good described in recent reviews $[6,54,62$, 71,72 , and many others]. Studies in this field have led to the view that intermittent hypoxia is the principal, if not the only, risk factor for the development of a number of detrimental cardiovascular, respiratory, metabolic, and cognitive outcomes [7]. The authors having analyzed a large number of studies concluded that protocols that were employed to establish the link between intermittent hypoxia and detrimental outcomes were typically severe in regards to intensity, duration, or both. The role of pattern, intensity, and duration of hypoxic application were largely ignored and the beneficial effects linked to milder forms of intermittent hypoxia were generally overlooked.

The balance between benefits and injury appears to primarily depend on the ability of the organism to activate adaptive mechanisms to IHT. In this context, the adaptive or maladaptive responses can be generally predicted by the frequency, severity, and duration of intermittent hypoxia [11]. However, the presence of underlying conditions such as hypertension or obesity, as well as age, sex, or genotypic variance, may be important factors tilting the balance between an appropriate homeostatic response and decompensation. Thus, careful monitoring for major functional performance during hypoxic sessions required when using the oxygen concentrations below $10 \%$ for fitness and sports, but for patients with various diseases as well as older people such medical monitoring must be carried out starting with $12 \% \mathrm{O} 2$. The duration and number of hypoxic episodes must be individually selected. 
Individual prescription of hypoxic regimes

Individual variability to breathing the same hypoxia air is remarkable. Although all individuals respond and their respiration and heart rate increase according to the drop in arterial oxygen saturation, the pattern and magnitude of the response significantly varies from person to person which was mentioned in early works [74 - 76]. To determine individual sensitivity to hypoxic exposure investigators use different hypoxic stress-tests (spiroergometer test, breathing with hypoxic mixture with certain oxygen concentration, rebreathing test, breathing through an additional dead space, breath-holding tests).

In order to establish an individual's type of hypoxia reaction it is advisable to complete a test for each person before they start a course of IHT. The literature describes just a few practical approaches to solving this problem [77 - 79].

Russian authors proposed to use the hypoxic test consisting of short term (several minutes) breathing of hypoxic air of known oxygen concentration (conventionally $\mathrm{FiO}_{2}=$ $11 \%$ ), followed by a recovery period, when the person takes the mask off and reverts to normal (ambient) air breathing $[80,81]$. But still now we could not find out how to use in practice the resulting test information for selecting a specific training mode.

Bassovitch \& Serebrovskaya [78] offered to analyze the shape of the $\mathrm{SpO}_{2}$ curve under breathing with $11 \% \mathrm{FiO}_{2}$ hypoxic mixture. When $\mathrm{SpO}_{2}$ reaches the targeted baseline of $85 \%$, the patient is instructed to take the mask off and revert to ambient air breathing. The person remains sitting until the arterial oxygen saturation recovers back to the normal level of $95 \%$. The specific methodology to use the results of this test for individual IHT mode selection has been described. However, in the later works, data validation of this technique in clinical or sport practice has not been published. The situation with the specific description of the principles of biofeedback control during the training session is also highly deplorable.
We know the only one laboratory where the study of individual reactions to hypoxia is given serious consideration and the proposed method of IHT mode selection was good described for older people with accelerated aging and patients with cardiovascular disorders and widely used in practice. This is the laboratory headed by Prof. O.Korkushko in the Institute of Gerontology, Kiev, Ukraine [28, 29, 77, 79].

During the past few years numerous debates about the ethical evaluation of diagnostic and therapeutic use of hypoxia in humans are raised. Although the works devoted to this problem obtained the approval from the Human Investigation Ethics Committees, there is the lack of evidences about strong evaluation of risk/ benefit ratio. The analysis of such ratio and the creation of standardized guidelines for hypoxic treatment/training application are complicated due to the differences in criteria for individual dosage and utilized methods.

\section{CONCLUSION}

Collectively, the results suggest that short episodes of normobaric intermittent hypoxia leads to a variety of physiological benefits with minimal risk. Three to 5 exposures to reduced inspired oxygen up to $12-10 \%, 5-7 \mathrm{~min}$ each during 2 to 3 weeks can be used for fitness and treatment of various diseases. More severe or longer intermittent hypoxia protocols must be accompanied by strict monitoring of respiratory and cardiovascular functions in order to avoid side effects. The reduction of oxygen content to individually tolerable level is justified for sports training and fitness as far as it effectively includes adaptation mechanisms and maximizes benefits. However, such regimen requires preliminary diagnostics of individual hypoxic tolerance and cardio-respiratory reactivity as well as rigorous monitoring of vital functions and good feedback device. The use of oxygen concentrations below $12 \%$ for treatment of diseases, especially in children and the elderly, are required substantial additional research. 
We appeal to all scientists working in this field not to hide their negative results but publish all observations in the open press. It will help a lot in developing common guidelines for IHT implementation to improve public health of our Planet.

\section{Т.В.Серебровская ${ }^{1}$, 3.А.Серебровская ${ }^{1}$, Е. Егоров ${ }^{2}$}

\section{ТРЕНИРОВОЧНЫЙ И ТЕРАПЕВТИЧЕ- СКИЙ ПОТЕНЦИАЛ ИНТЕРВАЛЬНОЙ ГИПОКСИИ: ВОПРОС ДОЗЫ}

Распространение в последнее десятилетие методов интервальной гипоксической тренировки (ИГТ) в фитнесе, спорте, военной и медицинской практике вызвало дискуссию о наиболее эффективных режимах гипоксической тренировки и методах ее инструментальной реализации. Низкие дозы гипоксии могут быть недостаточным стимулом для мобилизации адаптивных механизмов, в то время как глубокая или продолжительная гипоксия способна провоцировать опасные патологические процессы. В этом обзоре мы касаемся узкого практического вопроса о наиболее эффективной и удобной технологии реализации ИГТ, а именно методов, основанных на вдыхании человеком гипоксических газовых смесей. Данные, полученные при исследовании людей, убедительно свидетельствуют о том, что использование смесей с 15-13\% кислорода во вдыхаемом воздухе $\left(\mathrm{FiO}_{2}\right)$ при различных временных характеристиках не вызывает выраженных положительных изменений. Кратковременные ежедневные сеансы, состоящие из 5-7-минутных вдыханий $12-10 \% \mathrm{O}_{2}$, чередующихся с равными интервалами нормоксии, в течение 2-3 нед, считаются наиболее эффективными и безвредными как для фитнеса, так и лечения некоторых заболеваний. Протоколы с более жесткой или более длительной гипоксией должны сопровождаться строгим мониторингом жизненно важных функций для избежания побочных эффектов. Снижение на несколько минут содержания кислорода до индивидуально переносимого предела оправдано в спортивной практике, поскольку это максимизирует положительный эффект. Тем не менее, такой режим требует предварительной диагностики индивидуальной переносимости гипоксии и реактивности респираторно-гемодинамической системы, а также строгого контроля жизненно важных функций и хорошей обратной связи пациента с прибором. Использование концентрации кислорода ниже $12 \%$ для лечения заболеваний, особенно у детей и пожилых людей, требует серьезных дополнительных исследований. Недавно был предложен новый режим гипоксическо-гипероксической тренировки, сочетающий в себе периоды дыхания гипоксической $\left(12-10 \% \mathrm{FiO}_{2}\right)$ и гипероксической $\left(30-35 \% \mathrm{FiO}_{2}\right)$ смесью. Немногочисленные данные свидетельствуют, что такой режим может сократить время реоксигенации, т.е. уменьшить продолжительность тренировочных сессий. Однако, до сих пор нет достаточной сравнительной базы для доказательства, что этот метод является более эффективным, чем гипоксически-нормоксические режимы. Мы обращаемся ко всем ученым, работающим в области ИГТ, не скрывать свои негативные результаты, а публиковать все наблюдения в открытой печати. Это внесет значительный вклад в разработку общих методических принципов осуществления ИГТ для улучшения здоровья населения нашей планеты.

${ }^{1}$ Институт физиологии им. А.А.Богомольияа НАН
Украинь,, Киев, ${ }^{2}$ CELLGYM Technologies GmbH, Берлин,
Германия

Т.В.Серебровська ${ }^{1}$, 3.О.Серебровська ${ }^{1}$, С. Сгоров ${ }^{2}$

\section{ТРЕНУВАЛЬНИЙ І ТЕРАПЕВТИЧНИЙ ПОТЕНЦАЛ ІНТЕРВАЛЬНОЇ ГІПОКСІЇ: ПИТАННЯ ДОЗИ}

Поширення в останнє десятиліття методів інтервального гіпоксичного тренування (IГТ) у фітнесі, спорті, військовій та медичній практиці викликало дискусію про найбільш ефективні режими гіпоксичного тренування і методи їх інструментальної реалізації. Низькі дози гіпоксії можуть бути недостатнім стимулом для мобілізації адаптивних механізмів, у той час як глибока або тривала гіпоксія здатна провокувати небезпечні патологічні процеси. У цьому огляді ми торкаємося вузького практичного питання про найбільш ефективну і зручну технологію реалізації ІГТ, а саме методів, заснованих на вдиханні людиною гіпоксичних газових сумішей. Дані, отримані при дослідженні людей, переконливо свідчать про те, що використання сумішей з 15-13\% кисню у вдихуваному повітрі (FiO2) при різних часових характеристиках не викликає виражених позитивних змін. Короткочасні щоденні сеанси, що складаються з 5-7-хвилинних вдихань 12-10\% $\mathrm{O}_{2}$, що чергуються 3 рівними інтервалами нормоксіі, протягом 2-3 тиж, вважаються найбільш ефективними і нешкідливими як для фітнесу, так і лікування деяких захворювань. Протоколи 3 жорсткішою або більш тривалою гіпоксією повинні супроводжуватися суворим моніторингом життєво важливих функцій для уникнення побічних ефектів. Зниження на кілька хвилин вмісту кисню до межі, яка індивідуально переноситься, виправдано в спортивній практиці, оскільки це максимізує позитивний ефект. Тим не менше такий режим вимагає попередньої діагностики індивідуальної переносимості гіпоксії і реактивності респіраторно-гемодинамічної системи, а також суворого контролю життєво важливих функцій і хорошого зворотного зв'язку пацієнта з приладом. Використання концентрації кисню нижче за $12 \%$ для лікування захворювань, особливо у дітей і літніх людей, вимагає серйозних додаткових досліджень. Нещодавно був запропонований новий метод гіпоксично-гіпероксичного тренування, що 
поєднує в собі періоди дихання гіпоксичною (12-10\% $\left.\mathrm{FiO}_{2}\right)$ і гіпероксичною (30-35\% $\mathrm{FiO}_{2}$ ) сумішшю. Обмежені дані свідчать, що такий режим може скоротити час реоксигенації, тобто зменшити тривалість тренувальних сесій. Проте, до цих пір немає достатньої порівняльної бази для доказу, що цей метод є більш ефективним, ніж гіпоксично-нормоксичні режими. Ми звертаємося до всіх вченим, які працюють в галузі IГТ, не приховувати свої негативні результати, а публікувати всі спостереження у відкритій пресі. Це зробить значний внесок у розробку загальних методичних принципів здійснення IГТ для поліпшення здоров’я населення нашої планети.

${ }^{1}$ Інститут фізіології ім. О.О.Богомольия НАН України, Киї, ${ }^{2}$ CELLGYM Technologies GmbH, Берлін, Німеччина

\section{REFERENCES}

1. Prokopov AF. Intermittent Hypoxia and Health: From Evolutionary Aspects to Mitochondria Rejuvenation. In: Lei Xi \& Tatiana V. Serebrovskaya (Eds). Intermittent Hypoxia and Human Diseases / Springer, UK, 2012, Chapter 21, p. 253-69.

2. Gonzalez-Rothi EJ, Lee KZ, Dale EA, Reier PJ, Mitchell GS, Fuller DD. Intermittent hypoxia and neurorehabilitation. J Appl Physiol (1985). 2015 Dec 15; 119(12):145565.

3. Basovich SN. Trends in the use of preconditioning to hypoxia for early prevention of future life diseases. Biosci Trends. 2013 Feb; 7(1):23-32.

4. Dale EA, Ben Mabrouk F, Mitchell GS. Unexpected benefits of intermittent hypoxia: enhanced respiratory and nonrespiratory motor function. Physiology (Bethesda). 2014 Jan;29(1):39-48.

5. Navarrete-Opazo A, Mitchell GS. Therapeutic potential of intermittent hypoxia: a matter of dose. Am J Physiol Regul Integr Comp Physiol. 2014 Nov 15;307(10):R1181-97.

6. Dempsey JA, Morgan BJ. Humans In Hypoxia: A Conspiracy Of Maladaptation?! Physiology (Bethesda). 2015 Jul; 30(4):304-16.

7. Mateika JH, El-Chami M, Shaheen D, Ivers B. Intermittent hypoxia: a low-risk research tool with therapeutic value in humans. J Appl Physiol (1985). 2015 Mar 1;118(5):520-32.

8. Astorino TA, Harness ET, White AC. Efficacy of Acute Intermittent Hypoxia on Physical Function and Health Status in Humans with Spinal Cord Injury: A Brief Review. Neural Plast. 2015; 2015:409625.

9. Serebrovskaya TV, Xi L. Intermittent hypoxia in childhood: the harmful consequences versus potential benefits of therapeutic uses. Front Pediatr. 2015 May 19;3:44. doi: 10.3389/fped.2015.00044. eCollection 2015.

10. Serebrovska TV, Shatilo VB. Remote Ischemic Preconditioning versus Intermittent Hypoxia Training: a Comparative Analysis for Cardioprotection. Fiziol Zh. 2015, 61(3): 99-117.

11. Almendros I, Wang Y, Gozal D. The polymorphic and con- tradictory aspects of intermittent hypoxia. Am J Physiol Lung Cell Mol Physiol. 2014 Jul 15;307(2):L129-40.

12. Bassovitch $\mathrm{O}$. Intermittent hypoxic training: risks versus benefits. A biomedical engineering point of view. Eur J Appl Physiol. 2010 Oct;110(3):659-60.

13. Serebrovskaya TV, Nosar VI, Bratus LV, Gavenauskas BL, Mankovska IM. Tissue oxygenation and mitochondrial respiration under different modes of intermittent hypoxia. High Alt Med Biol. 2013 Sep;14(3):280-88.

14. Serebrovskaya TV. Intermittent Hypoxia Research in the Former Soviet Union and the Commonwealth of Independent States (CIS): History and Review of the Concept and Selected Applications. High Alt Med Biol. 2002 Summer;3(2):205-21.

15. Ando S, Hatamoto Y, Sudo M, Kiyonaga A, Tanaka H, Higaki Y. The effects of exercise under hypoxia on cognitive function. PLoS One. 2013 May 10; 8(5):e63630.

16. Turner G, Gibson OR, Maxwell NS. Simulated moderate hypoxia reduces intermittent sprint performance in games players. J Sports Med Phys Fitness. 2014 Oct;54(5):566-74.

17. Kong Z, Zang Y, Hu Y. Normobaric hypoxia training causes more weight loss than normoxia training after a 4-week residential camp for obese young adults. Sleep Breath. 2014 Sep;18(3):591-7.

18. Ho JY, Huang TY, Chien YC, Chen YC, Liu SY. Effects of acute exposure to mild simulated hypoxia on hormonal responses to low-intensity resistance exercise in untrained men. Res Sports Med. 2014;22(3):240-52.

19. Ramos-Campo DJ, Martínez-Sánchez F, Esteban-García P, Rubio-Arias JA, Clemente-Suarez VJ, Jiménez-Díaz JF. The effects of intermittent hypoxia training on hematological and aerobic performance in triathletes. Acta Physiol Hung. 2015 Dec;102(4):409-18.

20. Holliss BA, Fulford J, Vanhatalo A, Pedlar CR, Jones AM. Influence of intermittent hypoxic training on muscle energetics and exercise tolerance. J Appl Physiol (1985). 2013 Mar 1;114(5):611-9.

21. Goods P SR, Dawson BT, Landers GJ, Gore CJ, Peeling P. Effect of different simulated altitudes on repeat-sprint performance in team-sport athletes. Int J Sports Physiol Perform. 2014 Sep;9(5):857-62.

22. Brocherie F, Girard O, Faiss R, Millet GP.High-intensity intermittent training in hypoxia: a double-blinded, placebo-controlled field study in youth football players. J Strength Cond Res. 2015 Jan;29(1):226-37.

23. Ribon A, Pialoux V, Saugy JJ, Rupp T, Faiss R, Debevec T \& Millet GP. Exposure to hypobaric hypoxia results in higher oxidative stress compared to normobaric hypoxia. Respir Physiol Neurobiol. 2016 Mar;223:23-7.

24. Millet GP, Roels B, Schmitt L, Woorons X, Richalet JP. Combining hypoxic methods for peak performance. Sports Med. 2010 Jan 1;40(1):1-25.

25. Berezovskyi VA, Lisukha LM, Stepanova YI, Kolpacov IY. The influence of the normobaric hypoxia for the breathihg indexes of the children lived in radioactive contaminated territories. Fiziol Zh. 2015;61(3):35-43. [Ukrainian]. 
26. Querido JS, Welch JF, Ayas NT, Sheel AW. Cerebrovascular Response to CO2 Following 10 Days of Intermittent Hypoxia in Humans. Aerosp Med Hum Perform. 2015 Sep;86(9):782-6.

27. Lisukha LM, Berezovskiy VA. Influence of the normobaric hypoxia on visual-motor children's response lived in radioactively contaminated territories. Fiziol $\mathrm{Zh}$. 2015;61(2):40-7. [Ukrainian].

28. Shatilo VB, Korkushko OV, Ischuk VA, Downey HF, Serebrovskaya TV. Effects of intermittent hypoxia training on exercise performance, hemodynamics, and ventilation in healthy senior men. High Alt Med Biol. 2008 Spring;9(1):43-52.

29. Korkushko OV, Shatilo VB, Ishchuk VA. [Effectiveness of intermittent normabaric hypoxic trainings in elderly patients with coronary artery disease]. Adv Gerontol. 2010;23(3):476-82.

30. Serebrovskaya T.V., A.N. Bakunovsky, K.V. Nesvitailova, I. Mankovska. Intermittent hypoxia in treatment of bronchial asthma in childhood. Intermittent Hypoxia and Human Diseases, Springer, London, 2012, pp. 135-43.

31. Tadibi V, Dehnert C, Menold E, Bärtsch P. Unchanged anaerobic and aerobic performance after short-term intermittent hypoxia. Med Sci Sports Exerc. 2007 May;39(5):858-64.

32. Susta D, Dudnik E, Glazachev OS .A programme based on repeated hypoxia-hyperoxia exposure and light exercise enhances performance in athletes with overtraining syndrome: a pilot study. Clin Physiol Funct Imaging. 2015 Oct 7 [Epub ahead of print].

33. Zhang P, Shi X, Downey HF. Two-week normobaric intermittent-hypoxic exposures stabilize cerebral perfusion during hypocapnia and hypercapnia. Exp Biol Med (Maywood). 2015 Jul; 240(7):961-8.

34. Lyamina NP, Lyamina SV, Senchiknin VN, Mallet RT, Downey HF, Manukhina EB. Normobaric hypoxia conditioning reduces blood pressure and normalizes nitric oxide synthesis in patients with arterial hypertension. $\mathrm{J}$ Hypertens. 2011 Nov;29(11):2265-72.

35. Redzhebova OK, Chizhov AI. Results of utilization of intermittent normobaric hypoxia in patients with bronchial asthma and chronic obstructive bronchitis. Fiziol Zh. 1992;38:39-42. [Russian].

36. Zhang P, Downey HF, Chen S, Shi X. Two-week normobaric intermittent hypoxia exposures enhance oxyhemoglobin equilibrium and cardiac responses during hypoxemia. Am J Physiol Regul Integr Comp Physiol. 2014 Sep 15;307(6):R721-30.

37. Vorob'ev LP, Chizhov AIa, Potievskaia VI. The possibilities of using intermittent normobaric hypoxia for treating hypertension patients. Ter Arkh. 1994;66(8):12-5. [Russian].

38. Potievskaia VI, Chizhov AIa. Effect of intermittent normobaric hypoxia on dynamics of disease state in patients with hypertension. Fiziol Zh. 1992;38(5):53-7. [Russian].

39. Serebrovskaya TV, Nikolsky IS, Nikolska VV, Mallet RT, Ishchuk VA. Intermittent hypoxia mobilizes hema- topoietic progenitors and augments cellular and humoral elements of innate immunity in adult men. High Alt Med Biol. 2011 Fall;12(3):243-52.

40. Hayes H. B., A. Jayaraman, M. Herrmann, G. S. Mitchell, W. Z. Rymer, and R. D. Trumbower. Daily intermittent hypoxia enhances walking after chronic spinal cord injury: a randomized trial. Neurology. 2014; 82(2):104-13.

41. Hayes HB, Chavtal S, Ting LH, Rymer WZ, Mitchell GS, Trumbower RD. Effect of single-day acute intermittent hypoxia on overground walking speed and muscle coordination in persons with incomplete spinal cord injury. Soc Neurosci. 2012; Abstract: 252.17/M16.

42. Trumbower RD, Jayaraman A, Mitchell GS, Rymer WZ. Exposure to acute intermittent hypoxia augments somatic motor function in humans with incomplete spinal cord injury. Neurorehabil Neural Repair. 2012; 26: 163-72.

43. Yokhana SS, Gerst DG III, Lee DS, Badr MS, Qureshi T, Mateika JH. Impact of repeated daily exposure to intermittent hypoxia and mild sustained hypercapnia on apnea severity. J Appl Physiol (1985). 2012 Feb;112(3):367-77.

44. Beaudin AE, Waltz X, Pun M, Wynne-Edwards KE, Ahmed SB, Anderson TJ, Hanly PJ, Poulin MJ. Human intermittent hypoxia-induced respiratory plasticity is not caused by inflammation. Eur Respir J. 2015 Oct;46(4):1072-83.

45. Jaiswal PB, Tester NJ, Davenport PW. Effect of acute intermittent hypoxia treatment on ventilatory load compensation and magnitude estimation of inspiratory resistive loads in an individual with chronic incomplete cervical spinal cord injury. J Spinal Cord Med. 2016 Jan;39(1):103-10.

46. Tester NJ, Fuller DD, Fromm JS, Spiess MR, Behrman AL, Mateika JH. Long-term facilitation of ventilation in humans with chronic spinal cord injury. Am J Respir Crit Care Med. 2014 Jan 1;189(1):57-65.

47. Polotsky VY, Bevans-Fonti S, Grigoryev DN, Punjabi $\mathrm{NM}$, Intermittent Hypoxia Alters Gene Expression in Peripheral Blood Mononuclear Cells of Healthy Volunteers. PLoS One. 2015 Dec 14;10(12):e0144725.

48. Serebrovskaia ZA, Serebrovskaia TV, Afonina GB. Chemiluminescence, blood lipid peroxidation and neutrophil activity during the hypoxic training of persons subjected to ionizing radiation exposure. Radiats Biol Radioecol. 1996 May-Jun;36(3):394-9.

49. Serebrovs'ka TV, Kolesnikova IeE, Karaban' IM. Respiratory regulation during adaptation to intermittent hypoxia in patients with Parkinson disease. Fiziol Zh. 2003;49(3):95-103.

50. Roe PG, Jones JG. Analysis of factors which affect the relationship between inspired oxygen partial pressure and arterial oxygen saturation. Br J Anaesth. 1993 Oct;71(4):488-94.

51. Skjodt NM, Ritz C, Vethanayagam D.The pulse oxygen saturation: inspired oxygen pressure $\left(\mathrm{SpO}_{2}: \mathrm{P}_{\mathrm{I}} \mathrm{O}_{2}\right)$ diagram: application in the ambulatory assessment of pulmonary vascular disease. Adv Exp Med Biol. 2008; 605:492-6. 
52. Sanz F, Dean N, Dickerson J, Jones B, Knox D, FernándezFabrellas E, Chiner E, Briones ML, Cervera Á, Aguar $\mathrm{MC}$, Blanquer J. Accuracy of $\mathrm{PaO}_{2} / \mathrm{FiO}_{2}$ calculated from $\mathrm{SpO}_{2}$ for severity assessment in ED patients with pneumonia. Respirology. 2015 Jul; 20(5):813-8.

53. Lukyanova LD, Kirova YI. Mitochondria-controlled signaling mechanisms of brain protection in hypoxia. Front Neurosci. 2015 Oct 1;9:320.

54. Yin F, Cadenas E. Mitochondria: the cellular hub of the dynamic coordinated network. Antioxid Redox Signal. 2015 Apr 20;22(12):961-4.

55. Foster GE, McKenzie DC, Milsom WK, Sheel AW. Effects of two protocols of intermittent hypoxia on human ventilatory, cardiovascular and cerebral responses to hypoxia. J Physiol. 2005 Sep 1;567(Pt 2):689-99.

56. Katayama K, Sato Y, Morotome Y, Shima N, Ishida K, Mori S, Miyamura M. Intermittent hypoxia increases ventilation and $\mathrm{SpO} 2$ during hypoxic exercise and hypoxic chemosensitivity. J Appl Physiol 2001, 90: 1431-40.

57. Katayama K, Sato Y, Shima N, Qiu JC, Ishida K, Mori S, Miyamura M. Enhanced chemosensitivity after intermittent hypoxic exposure does not affect exercise ventilation at sea level. Eur J Appl Physiol. 2002; 87: 187-91.

58. Koehle M, Sheel W, Milsom W, McKenzie D. The effect of two different intermittent hypoxia protocols on ventilatory responses to hypoxia and carbon dioxide at rest. Adv Exp Med Biol. 2008, 605:218-23.

59. Katayama K, Ishida K, Iwasaki KI, Miyamura M.Effect of two durations of short-term intermittent hypoxia on ventilatory chemosensitivity in humans. Eur J Appl Physiol. 2009 Mar;105(5):815-21.

60. Mitchell GS, Terada J. Should we standardize protocols and preparations used to study respiratory plasticity? Respir Physiol Neurobiol. 2011 Jul 31;177(2):93-7.

61. Peng YJ, Prabhakar NR. Effect of two paradigms of chronic intermittent hypoxia on carotid body sensory activity. J Appl Physiol (1985). 2004 Mar;96(3):1236-42.

62. Prabhakar NR, Semenza GL. Adaptive and maladaptive cardiorespiratory responses to continuous and intermittent hypoxia mediated by hypoxia-inducible factors 1 and 2 . Physiol Rev. 2012 Jul;92(3):967-1003.

63. Anokhin II, Geppe NA, Dairova PA, Zhupikova NI, Melnikova EV, Selezneva IN, Urbakh VA. [Effects of hypoxic stimulation in experimental animals and in children with bronchial asthma]. Fiziol.Zh. 38 (1992) 33-9. [Russian].

64. Maldonado M, Portela LO. Analysis of physiological variables during acute hypoxia and maximal stress test in adolescents clinically diagnosed with mild intermittent or mild persistent asthma. J Bras Pneumol. 2011 Nov-Dec;37(6):712-9.

65. Lopata VA, Serebrovskaya TV. Hypoxicators: review of the operating principles and constructions. Intermittent Hypoxia and Human Diseases, Springer, London, 2012, pp. 291-302.

66. Arkhipenko YV, Sazontova TG, Zhukova AG. Adaptation to periodic hypoxia and hyperoxia improves resistance of membrane structures in heart, liver, and brain. Bull Exp Biol Med. 2005 Sep;140(3):278-81.
67. Glazachev OS, Dudnik EN. Microcirculatory reactivity features in almost healthy people during acute moderate hypoxia and hyperoxia modeling. Fiziol Cheloveka. 2013 Jul-Aug;39(4):74-81. [Russian].

68. Sazontova TG, Bolotova AV, Bedareva IV, Kostina NV, and Arkhipenko YuV. Adaptation to intermittent hypoxia/ hyperoxia enhances efficiency of exercise training. In: Lei Xi \& Tatiana V. Serebrovskaya (Eds). Intermittent Hypoxia and Human Diseases / Springer, UK, 2012, Chapter 16, p. 191-205.

69. Gonchar O, Mankovska I. Moderate hypoxia/hyperoxia attenuates acute hypoxia-induced oxidative damage and improves antioxidant defense in lung mitochondria. Acta Physiol Hung. 2012 Dec;99(4):436-46.

70. Glazachev OS, Zvenigorodskaia LA, Dudnik EN, Iartseva LA, Mishchenkova TV, Platonenko AV, Spirina GK. Interval hypoxic-hyperoxic training in the treatment of the metabolic syndrome. Eksp Klin Gastroenterol. 2010;(7):51-6.

71. Drager LF, Polotsky VY, O’Donnell CP, Cravo SL, Lorenzi-Filho G, Machado $\mathrm{BH}$. Translational approaches to understanding metabolic dysfunction and cardiovascular consequences of obstructive sleep apnea. Am J Physiol Heart Circ Physiol. 2015 Oct;309(7):H1101- 11.

72. Eisele HJ, Markart P, Schulz R. Obstructive Sleep Apnea, Oxidative Stress, and Cardiovascular Disease: Evidence from Human Studies. Oxid Med Cell Longev. 2015;2015:608438.

73. Weiss MD, Tamisier R, Boucher J, Lynch M, Gilmartin G, Weiss JW, Thomas RJ. A pilot study of sleep, cognition, and respiration under 4 weeks of intermittent nocturnal hypoxia in adult humans. Sleep Med. 2009 Aug;10(7):739-45.

74. Berezovskiı̌ VA, Serebrovskaia TV, Lipskiı̌ PIu.[Study of external respiratory function in twins with different gas mixtures] Fiziol Zh. 1981 Jan-Feb;27(1):20-5 [Ukrainian].

75. Berezovskii VA, Serebrovskaia TV. [Individual reactivity of the human respiratory system and its evaluation]. Fiziol Zh. 1988 Nov-Dec;34(6):3-7 [Ukrainian].

76. Tsvetkova A.M. and Tkatchouk E.N.["Hypoxia User": the opportunity of individual programming of interval hypoxic training]. In: Hypoxia: Mechanisms, Adaptation, Correction. Moscow, BEBIM, 1999; pp.83-4. [Russian].

77. Korkushko OV, Shatilo VB, Ishchuk VA, Tourta MI. Use of intermittent normobaric hypoxia trainings in elderly people. In: Xi L, Serebrovskaya TV (Eds). Intermittent hypoxia: from molecular mechanisms to clinical applications. Nova Science Publishers, Inc, New York, 2009; Chapter 28, p. 537-48.

78. Bassovitch O. and Serebrovskaya T. Equipment and Regimes for Intermittent Hypoxia Therapy. In: Intermittent Hypoxia: From Molecular Mechanisms to Clinical Applications/. Editors: Lei Xi \& Tatiana V. Serebrovskaya/ Nova Science Publishers, 2009, Chapter 30 : 539-601.

79. Shatylo VB, Serebrovska TV, Gavalko AV, Egorov E, and Korkushko OV. Acute hypoxic test in patients with 
prediabetes. High Alt Med Biol. 2016 (in press).

80. Strelkov RB. (Ed.) Normobaric Hypoxytherapy: Methodological Recommendations. Ministry of Public Health. Moscow, 1988, 24 p. [Russian].
81. Tsyganova TN, Egorova EB (Eds.). Interval Hypoxic Training in Obstetrics and Gynaecology. Methodological Recommendations. Ministry of Public Health. Moscow, 1993, 18 p. [Russian]. 